\title{
EU health law and policy: shaping a future research agenda
}

\author{
Eleanor Brooks ${ }^{1 \star}$ (D) and Mary Guy ${ }^{2}$ \\ ${ }^{1}$ Lecturer in Health Policy, Global Health Policy Unit, University of Edinburgh, Edinburgh, UK and ${ }^{2}$ Lecturer in Law, \\ Lancaster Law School, Lancaster University, Lancaster, UK \\ ${ }^{*}$ Corresponding author. Email: eleanor.brooks@ed.ac.uk
}

(Received 13 July 2020; accepted 25 July 2020; first published online 24 August 2020)

\begin{abstract}
The relevance of the European Union (EU) for health has been widely recognised within the health community for some time, and is increasingly apparent to European policy-makers and publics. Despite being an area of policy that national governments would prefer to keep exclusive control of, and though in the past it has rarely been at the top of the agenda, many elements of health have been gradually 'Europeanised'. This special issue marks the culmination of a British Academy-funded project - EU Health Law and Policy: Shaping a Future Research Agenda - which sought to build on the growing web of expertise in this field and reflect upon the future of health as an EU competence, at a time when it appeared to be under threat.
\end{abstract}

Key words: European Union; health; health law; health policy

\section{Introduction}

The relevance of the European Union (EU) for health has been widely recognised within the health community for some time, and is increasingly apparent to European policy-makers and publics. Despite being an area of policy that national governments would prefer to keep exclusive control of, and though in the past it has rarely been at the top of the agenda, many elements of health have been gradually 'Europeanised'. Largely as a result of the creation of the internal market, which provides for the free movement for goods, people, services and capital, national health systems must take account of EU rules concerning pharmaceutical safety, the quality of blood products, recognition of health professional qualifications, the right to treatment in another state and competition between health service providers, among countless others. Health systems are also shaped by EU policies, networks and guidance on issues such as cancer care, assessment of health technologies, implementation of eHealth infrastructure, tackling obesity and communicable diseases, with the latter currently at the fore amid the coronavirus (COVID-19) pandemic. The articles in this special issue were written prior to the outbreak of COVID-19 but the dynamics, themes and challenges that they describe provide crucial underpinning to discussions about the future of the EU's role in health, both of which will doubtlessly intensify over the coming months.

EU health law and policy has emerged as a sub-field in its own right over the last 20 years. The body of law and political science literature within it spans both broad overviews of the field (notably McKee and Mossialos, 2002; McKee et al., 2002; Hervey and McHale, 2004, 2015; Steffen, 2005; Mossialos et al., 2010; van de Gronden et al., 2011; Greer et al., 2014, 2019; Hervey et al., 2017; Den Exter, 2018), and more focused case studies of particular sectors, issues or dynamics (cf. Greer, 2009; Hancher and Sauter, 2012; Flear et al., 2013; Greer and Kurzer, 2013; Alemanno and Garde, 2015; de Ruijter, 2019; Guy, 2019). 
This special issue marks the culmination of a British Academy-funded project - EU Health Law and Policy: Shaping a Future Research Agenda - which sought to build on this growing web of expertise and reflect upon the future of health as an EU competence, at a time when it appeared to be under threat.

\section{What future for the EU health agenda?}

In March 2017 the European Commission published a White Paper on the future of Europe, outlining a series of possible scenarios for EU integration and the future of the Union. One of these scenarios depicted a scaling back of EU action on health, describing this as an area having 'limited added value' (European Commission, 2017: 22). Published around half way through Jean-Claude Juncker's Presidency, which had already seen health slip down the agenda (Brooks, 2018), the White Paper drew criticism and concern from the Brussels health community (EPHA, 2017). These sentiments were further compounded by rumours that the health directorate (DG SANTE) might be disbanded in the 2019 re-organisation of the Commission (Science Business, 2018; Politico, 2019).

This period of uncertainty has come at an important time for the study of EU health governance. The academic and policy literature now offers a comprehensive account of the areas where national health policies come into contact with EU law, a variety of examples of EU health cooperation, and an insight into the drivers of this integration, given the absence of a strong legal mandate. The dominant finding is that EU health policy has not been driven forward by overarching objectives or mandates, nor by consistent political will on the part of national governments. Rather, it has been driven by entrepreneurialism and opportunism on the part of Commission officials, supported by the Court of Justice of the EU (CJEU), and facilitated by strong EU powers and functional pressures in tangential fields, such as competition, occupational health and safety and the internal market (Greer, 2006, 2008; Lamping and Steffen, 2009). Correspondingly, EU health law has developed as a field in its own right, but is fundamentally transversal in nature, drawing on diverse aspects of EU law governing tangential fields beyond a limited public health Treaty competence (Hervey and McHale, 2004, 2015; Hancher and Sauter, 2012; Guy and Sauter, 2017).

Whilst the powers in these tangential fields have remained unchanged, what seemed to dissipate, under the Juncker Presidency, was the space available for entrepreneurialism and opportunism. The Juncker Commission was narrowly focused and more closely managed than its predecessor Brooks and Burgin (2020). The tasks of the Health Commissioner were precisely described and limited to crisis preparedness, genetically modified organisms, pharmaceuticals, health system performance assessment and the EU's response to Ebola (European Commission, 2014). Items not on this agenda, or able to demonstrate close links to one of the President's 10 priority projects, were unlikely to pass the gatekeepers in DG Secretariat General, whose role had been elevated to implementers of the President's 'political guidelines'. Officials interviewed as part of other projects at this time described a 'glass ceiling' above the entrepreneurship of DG SANTE and the Health Commissioner, Vytenis Andriukaitis.

Despite these challenges, progress in developing EU health governance was made in several areas. The European Reference Networks for rare diseases, the legislative proposal on Health Technology Assessment and the State of Health in the EU initiative, for instance, were all institutionalised under the Juncker Presidency and marked considerable achievement. Yet, given the leading role played by DG SANTE and its officials in the development of EU health policy to date, the constraints and uncertainties facing health under the Juncker Presidency raised some important questions about the future of EU health governance. Which policy areas would suffer - either from stagnation or dismantling - in the new, curtailed environment? Which might come to the fore, be newly identified, or continue to develop unabated? Who or what now would be the driving force behind EU action on health? It was these questions which prompted the submission 
of an application, in May 2017, to the British Academy small research grant competition and the launch of the project, EU Health Law and Policy (EUHLP): Shaping a Future Research Agenda.

\section{The EUHLP project and the contents of the special issue}

The project brought together colleagues studying or involved in EU health governance. An initial World Café workshop reflected on impressions of the research field and its future trajectory, and a number of key themes were distilled (Brooks and Guy, 2018). A handful of these were taken forward to a second workshop, in which they were developed into the research articles contained here. Throughout the project, we have sought to include scholars from the UK, the EU and beyond, from the academic and policy worlds, from law and political science, and from early career and established positions. In addition to contributing to the project's broader aims of establishing a network and supporting early career colleagues, our goal was to seek input from across disciplines, backgrounds and specialisms. We embedded this within the peer review process, for instance, to ensure that articles spoke to audiences beyond their own disciplinary niches. The result is a series of articles that explore both the broad, systemic and institutional questions of EU health law and policy, and examples of specific policy areas that make up the substance of contemporary EU action on health.

The special issue opens with one of the biggest questions in global public health: how do we make commitments to 'take account of health' in other policy areas - known as the Health in All Policies (HiAP) principle - enforceable? The EU treaties have contained a commitment to the mainstreaming of health concerns since the 1992 Maastricht Treaty, yet action by the Courts to enforce this requirement has been limited - perhaps most notably to the Philip Morris case in challenging the Tobacco Products Directive. In their article, Bartlett and Naumann develop a 'split approach', distinguishing policy implementation from policymaking, to enable better understanding of the mainstreaming obligation in Article 168(1) Treaty on the Functioning of the European Union (TFEU). They further demonstrate how this approach could help the CJEU to identify breaches of Article 168(1) TFEU in cases where HiAP tools may not be used effectively to protect the health of EU citizens.

Three articles then address issues that have been identified as priorities for the EU in the 20192024 period: antimicrobial resistance (AMR), mental health and medical devices.

Deruelle offers an in-depth analysis of cooperation between the EU's three core agencies in the health field - the European Medicines Agency (EMA), the European Food Safety Authority (EFSA) and the European Centre for Disease Prevention and Control (ECDC). Looking specifically at how these agencies work together within the EU's AMR initiatives, the article finds that, whilst the early period of cooperation might be characterised by perception of threat and the practice of 'turf wars' between agencies, this soon gives way to a process of reflection and rebalancing, in which each agency (re)defines its unique role and contribution. Offering insight into how inter-agency cooperation might best be fostered in future, Deruelle notes that clear and appropriate task allocation by the European institutions, based on the existing expertise and capacities of the agencies involved, has been key to finding equilibrium between agency partners, and thus to lending credibility to the EU's AMR commitments.

Edquist uses the priority issue of mental health to study how practices of EU health governance are shaped by transnational logics, and what implications this has for the participation of citizens in health governance. The article traces global logics of neoliberalism and their influence on EU governance frameworks such as the Open Method of Coordination, where tools of best practice and benchmarking drew on New Public Management approaches to promote efficiency and competitiveness. The article shows how the utilisation of these approaches has structured relations among the EU institutions, non-governmental organisations (NGOs) and citizens, and shaped specific mental health discourses. Edquist concludes that these practices have shifted the debate to one in which mental health is framed as a disease burden, rather than a pillar of 
public health, and that they preclude a full and independent role for citizens in the EU policy process.

A final priority area - that of medical devices - is explored by Jarman, Rozenblum and Huang. In the wake of successive scandals involving devices approved for use by the EU regulatory system, their article provides a practical illustration of the problem with the EU's regulatory state model. Though adoption of regulation occurs at the EU level, implementation and, crucially, the resourcing of this implementation, is devolved to member states. The 2017 medical device regulation reforms make a number of changes in response to documented weaknesses in the existing 'essential requirements' for safety, the CE marking system, clinical evaluation requirements and the delegation of authority to Notified Bodies. However, they do nothing to address the over-reliance on the private sector and member state agencies, whose expertise and capacity is variable. As such, Jarman, Rozenblum and Huang conclude, there is a high risk that the EU's non-harmonised, non-precautionary regime will prevail, and the risk to human health continue.

In addition to these priority areas, the significance of non-health fields in shaping the future of EU health governance and national health systems should not be underestimated. Two further articles engage with the different ways in which EU competition law and state aid rules interact with health care.

Danieli addresses the question of the appropriate role for EU competition law in tackling excessive pricing abuses in the pharmaceutical industry, within the wider context of EU pharmaceutical regulation. The decisions of two national competition authorities regarding overcharging by pharmaceutical companies are examined: Aspen in Italy, and Pfizer and Flynn Pharma in the UK. These cases are juxtaposed with the wider EU competition law framework to demonstrate the potential for both competition law and regulation to play roles in tackling the problem of high prices for drugs, and to highlight scope for solutions at national and EU levels.

Van de Gronden and Guy consider the development of the EU courts' approach to defining the applicability of competition law in a health care context. To take effect, the prohibitions on anticompetitive agreements and abuse of dominance, and the state aid rules, both require the existence of an 'undertaking', or an economic activity consisting of offering goods or services on a market. Cases such as Ambulanz Glöckner, AOK Bundesverband and FENIN, created a broad framework in which health care providers may typically be considered subject to competition law, but health care purchasers (or managing bodies) may not be. However, classifying activities in this way in a health care context adds to wider controversies surrounding competition in health care. Van de Gronden and Guy suggest that a more effective way of classifying 'undertakings' in health care may lie in focusing on questions of public funding and public interest activities. In this article they apply the approach taken in the CEPPB state aid case (regarding financing of Spanish educational establishments) to the health care context for the first time, by re-examining a Dutch government subsidy of non-invasive prenatal testing.

The final article in this issue takes a step back and considers the EU's health governance in comparison with that of other federal systems. In so doing, it reveals some serious structural flaws. Greer illustrates how imbalances in the EU's founding treaties, which favour marketbuilding over market-cushioning policies, have led the EU to evolve as a neofunctional regulatory state. This has meant that, whilst most federations follow a model whereby risk is pooled and health financed at the highest possible level, and services are delivered at the local level, the EU does the opposite. It leaves risk pooling and financing to the member states, while regulating many aspects of health care at the highest level. This model of regulating without compensation is a risky one, Greer concludes, since smaller and periphery states struggle to meet the demands put on them by EU regulation and are often left disadvantaged, stoking inequalities and discontent. Crucially, however, Greer notes that this path is not predetermined. The evolution of EU health governance has been shaped by the ideologies and interests of national governments, and will continue to reflect the will and commitments of national leaders. 
The articles draw a wide range of conclusions but, taken collectively, present three key insights about the future of EU health governance.

Confirming the consensus within the literature to date, the first is that law and policy from non-health sectors is as important for EU health governance as the body of law and policy that explicitly targets health. Jarman, Rozenblum and Huang's article illustrates how internal market logics underpin the regulation of medical devices, whilst Danieli, Guy and van de Gronden highlight the importance of the competition law regime in the governance of access to pharmaceuticals and delivery of other health-related goods and services. Greer hints at the continued significance of the EU's fiscal framework for health, and Bartlett and Naumann, taking these findings as a starting point, argue for an interpretation of the treaties that enables better enforcement of the EU's commitment to make all policies work for the benefit of health.

This point leads into a second insight, which is that EU health governance is inherently interdisciplinary. In addition to requiring the mainstreaming of health into a wide range of ancillary sectors, strong public health requires cooperation among and insight from actors with different expertise and specialisms (as Deruelle's article illustrates). Though collaboration between different scientific disciplines is common in public health, collaboration between different policy disciplines (social, economic, environmental and commercial) is less well established in EU health governance, despite repeated efforts to 'break down silos' (Juncker, 2014).

Finally, the articles in the special issue point to the relevance of developments beyond the EU at the global, regional and local levels - for EU health governance. Most explicitly, Edquist's article illustrates the role of global logics in shaping EU governance practices, but Guy and van de Gronden also highlight the importance of national experience in informing the development of EU legal frameworks, and Greer explains the relevance of national welfare systems for EU social integration. As the literatures on Europeanisation and health law have long acknowledged, our understanding of EU health governance can only be furthered by taking account of structures above, below and outside of the EU itself (Lenschow, 2006; Hervey and McHale, 2015).

\section{The future of EU health law and policy: beyond the EU, beyond EU studies?}

In their postscript, Brooks and de Ruijter explore what these insights about EU health governance mean for the academic study of this field. They focus in particular on the latter two points, reflecting on the need for interdisciplinary collaborations, and the relevance of knowledge at the global, regional and local levels. Writing in June 2020, their closing piece considers the findings of the articles but also the implications of the COVID-19 pandemic, and how the location of authority in health law and policy might shift further still, as national, European and global responses are institutionalised.

We end this stage of the EU Health Law and Policy project in a very changed environment, but one which nevertheless reflects where we started - in a position where the context of EU health law and policy is shifting and a marked change to the EU's role in health in the near future seems likely. Some positive movement was already apparent in late 2019 as the new European Commission, led by President Ursula von der Leyen, began its term in office. The incoming Commissioner for Health, Stella Kyriakides, has been given a considerably more substantive 'mission' than her predecessor (Brooks, 2019), encompassing 12 priorities in total; six on food safety and animal and plant health, and six on 'protecting and promoting public health'. Gone are the references to the 'limited' health tasks given to the EU under the treaties and the need to 'respect [...] the rules on subsidiarity and proportionality' which filled the preamble of the 2014 agenda (European Commission, 2019). In their place is a statement of the need to 'support the health sector and the professionals working within it, to invest in new technologies, to promote healthy lifestyles and to cooperate better within the EU'. Such sentiments have only been amplified in the response to COVID-19 Brooks, de Ruijter and Greer (2020). As we write, the European Commission has announced a post-pandemic recovery plan worth $€ 1.85$ trillion, and replaced 
the current $€ 413$ million health budget with a commitment of $€ 1.7$ billion for the $2021-2027$ period (European Commission, 2020). Much of this increase is to support pandemic response and strengthen health system resilience against future crises, but it also contains provision for continuing the fight against AMR, tackling non-communicable diseases, scaling up the European Reference Networks for rare diseases and reducing health inequalities, among other goals. As such, a new chapter of EU health governance is clearly beginning. We are delighted to present this selection of articles to inform the further development of both the EU's health law and policy, and the academic study of it.

\section{References}

Alemanno A and Garde A (2015) Regulating Lifestyle Risks: The EU, Alcohol, Tobacco and Unhealthy Diets. Cambridge: Cambridge University Press.

Brooks E (2018) Review: Tamara K. Hervey, Calum Alasdair Young, and Louise E. Bishop (eds), Research handbook on EU health Law and policy, Edward Elgar, 2017. Medical Law Review 26, 165-176.

Brooks E (2019) A New European Commission for Health?', Global Health Policy Unit Blog, 20 December 2019. Available at https://ghpu.sps.ed.ac.uk/a-new-european-commission-for-health/ (last accessed 15 January 2020).

Brooks and Burgin A (2020) Political steering in the European Commission: a comparison of the energy and health sectors. Journal of European Integration. forthcoming.

Brooks E and Guy MJ (2018) European Union Health Law and Policy - Shaping a Future Research Agenda: Outcomes Document, Lancaster. Available at SSRN https://papers.ssrn.com/sol3/papers.cfm?abstract_id=3196933

Brooks E, de Ruijter A and Greer S (2020) COVID-19 and European Union health policy: from crisis to collective action In Social Developments in the European Union 2020. forthcoming.

Den Exter A (ed.) (2018) European Health Law. Apeldoorn: Maklu.

de Ruijter A (2019) EU Health Law \& Policy: The Expansion of EU Power in Public Health and Health Care. Oxford: Oxford University Press.

EPHA European Public Health Alliance (2017) Dear President Juncker, EU Health Collaboration is crucial for Europe's future, 2 June 2017. Available at https://epha.org/eu-health-collaboration-crucial-for-europe-future/ (Accessed 20 December 2019).

European Commission (2014) Mission Letter from President Juncker to Commissioner Andriukaitis, Brussels. Available at https://ec.europa.eu/commission/commissioners/sites/cwt/files/commissioner_mission_letters/andriukaitis_en.pdf (Accessed 29 May 2020).

European Commission (2017) White Paper on the Future of Europe, Brussels. Available at https://ec.europa.eu/commission/ future-europe/white-paper-future-europe/white-paper-future-europe-five-scenarios_en (Accessed 20 December 2019).

European Commission (2019) Mission Letter from President von der Leyen to Commissioner Kyriakides, Brussels. Available at https://ec.europa.eu/commission/sites/beta-political/files/mission-letter-stella-kyriakides_en.pdf (Accessed 29 May 2020).

European Commission (2020) Proposal for a Regulation of the European Parliament and of the Council on the establishment of a Programme for the Union's action in the field of health for the period 2021-2027 and repealing Regulation (EU) No 282/2014 ('EU4Health Programme'), COM(2020) 405 final, Brussels, 28.5.20.

Flear ML, Farrell A-M, Hervey TK and Murphey T (eds) (2013) European Law and New Health Technologies. Oxford: Oxford University Press.

Greer SL (2006) Uninvited Europeanization: neofunctionalism and the EU in health policy. Journal of European Public Policy 13, 134-152.

Greer SL (2008) Choosing paths in European Union health services policy: a political analysis of a critical juncture. Journal of European Social Policy 18, 219-231.

Greer SL (2009) The Politics of European Union Health Policies. Berkshire: Open University Press.

Greer SL and Kurzer P (eds) (2013) European Union Public Health Policy: Regional and Global Trends. Abingdon: Routledge.

Greer SL, Fahy N, Elliott H, Wismar M, Jarman H and Palm W (2014) Everything You Always Wanted to Know about European Union Health Policies but were Afraid to Ask. Copenhagen: WHO Regional Office for Europe.

Greer SL, Fahy N, Rozenblum S, Jarman H, Palm W, Elliot H and Wismar M (2019) Everything You Always Wanted to Know about European Union Health Policies but were Afraid to Ask, 2nd Edn. Copenhagen: WHO Regional Office for Europe.

Guy MJ (2019) Competition Policy in Healthcare - Frontiers in Insurance-Based and Taxation-Funded Systems. Cambridge: Intersentia.

Guy M and Sauter W (2017) The history and scope of EU health law and policy. In Hervey T, Young C and Bishop L (eds), Research Handbook on EU Health Law and Policy. Cheltenham: Edward Elgar, pp. 17-35.

Hancher L and Sauter W (2012) EU Competition and Internal Market Law in the Healthcare Sector. Oxford: Oxford University Press. 
Hervey T and McHale J (2004) Health Law and the European Union. Cambridge: Cambridge University Press.

Hervey T and McHale J (2015) European Union Health Law: Themes and Implications. Cambridge: Cambridge University Press.

Hervey T, Young C and Bishop L (eds) (2017) Research Handbook on EU Health Law and Policy. Cheltenham: Edward Elgar.

Juncker J-C (2014) A New Start for Europe: My Agenda for Jobs, Growth, Fairness and Democratic Change, Strasbourg. Available at https://ec.europa.eu/commission/sites/beta-political/files/juncker-political-guidelines-speech_en.pdf (Accessed 29 May 2020).

Lamping W and Steffen M (2009) European Union and health policy: the "chaordic" dynamics of integration. Social Science Quarterly 90, 1361-1379.

Lenschow A (2006) Europeanisation of public policy. In Richardson J (ed.), European Union: Power and Policy-Making, 3rd Edn. Abingdon: Routledge, pp. 55-69.

McKee M and Mossialos E (2002) EU Law and the Social Character of Healthcare. Brussels: Peter Lang.

McKee M, Mossialos E and Baeten R (eds) (2002) The Impact of EU Law on Health Care Systems. Brussels: Peter Lang.

Mossialos E, Permanand G, Hervey T and Baeten R (eds) (2010) Health Systems Governance in Europe: The Role of European Union Law and Policy. Cambridge: Cambridge University Press.

Politico (2019) Q and A with DG SANTE boss Anne Bucher', Carmen Paun, 7 June 2019. Available at https://www.politico. eu/article/q-and-a-with-dg-sante-boss-anne-bucher/ (Accessed 20 December 2019).

Science Business (2018) Will there be an EU health commissioner from 2020? Andriukaitis 'believes' so, Éanna Kelly, 31 May 2018. Available at https://sciencebusiness.net/news/will-there-be-eu-health-commissioner-2020-andriukaitis-believes-so (Accessed 20 December 2019).

Steffen M (ed.) (2005) Health Governance in Europe: Issues, Challenges and Theories. Abingdon: Routledge.

van de Gronden J, Szyszczak E, Neergaard U and Krajewski M (eds) (2011) Health Care and EU Law. The Hague: Springer.

Cite this article: Brooks E, Guy M (2021). EU health law and policy: shaping a future research agenda. Health Economics, Policy and Law 16, 1-7. https://doi.org/10.1017/S1744133120000274 